\title{
A review of Ireland's
}

waterbirds, with emphasis on wintering migrants and reference to H5N1 avian influenza

Crowe $\mathrm{O}^{1}$, Wilson $\mathrm{J}^{2}$, Aznar $\mathrm{I}^{3}$ and More $\mathrm{SJ}^{3}$

${ }^{1}$ Birdwatch Ireland, P.O. Box 12, Greystones, Co. Wicklow, Ireland

${ }^{2}$ National Parks and Wildlife Service, Department of the Environment, Heritage and Local Government, 7 Ely Place, Dublin 2, Ireland

${ }^{3}$ Centre for Veterinary Epidemiology and Risk Analysis, UCD Agriculture, Food Science and Veterinary Medicine, University College Dublin, Belfield, Dublin 4, Ireland

\section{ABSTRACT}

Ireland is characterised by its diversity and large abundance of wetlands, making it attractive to a wide variety of waterbirds throughout the year. This paper presents an overview of Ireland's waterbirds, including ecological factors relevant to the potential introduction, maintenance, transmission and spread of infectious agents, including the H5N1 avian influenza virus, in Ireland. Particular emphasis is placed on five groups of wintering migrants (dabbling and sieving wildfowl, grazing wildfowl, diving wildfowl, waders and gulls), noting that the H5N1 avian influenza virus has mainly been isolated from this subset of waterbirds. Ireland's wetlands are visited during the spring and summer months by hundreds of thousands of waterbirds which come to breed, predominantly from southern latitudes, and during the autumn and winter by waterbirds which come from a variety of origins (predominantly northern latitudes), and which are widely distributed and often congregate in mixed-species flocks. The distribution, feeding habits and social interactions of the five groups of wintering migrants are considered in detail. Throughout Ireland, there is interaction between different waterbird populations (breeding migrants, the wintering migrants and resident waterbird populations). There is also a regular and complex pattern of movement between feeding and roosting areas, and between wetlands and farmland. These interactions are likely to facilitate the rapid transmission and spread of the H5N1 avian influenza virus, if it were present in Ireland.

KEYWORDS: East Atlantic flyway, epidemiology, H5N1, Ireland, waterbirds, winter migration

Irish Veterinary Journal Volume 62 Number 12 800-811 2009

\section{INTRODUCTION}

The wetlands of northwest Europe are internationally important for millions of waterbirds, both resident and migratory. During summer months, waterbirds migrate to these wetlands to breed, whereas in winter, northern and boreal-nesting species migrate to these wetlands, either to overwinter or on passage to wintering grounds further south. Other waterbirds are year-round residents. Ireland plays a critical role in the ecology of these waterbirds, given its strategic location (on a major flyway), its mild (generally ice-free) climate and abundance of wetlands (Crowe 2005). An understanding of waterbird ecology is important to disease epidemiology, noting the role of these birds in the maintenance and spread of low pathogenic avian influenza (LPAl) (Webster et al. 1992). As yet, however, the role of waterbirds in the epidemiology of highly pathogenic avian influenza (HPAI) H5N1 of Asian lineage remains unclear and developing. The current outbreak of HPAI H5N1 was first detected in China in 1996 (Webster et al. 2007a), and has subsequently appeared in many countries in Asia, Europe and Africa (Kilpatrick et al. 2006). Ongoing studies are highlighting substantial differences in the behaviour of HPAI H5N1 and previous Al viruses, suggesting that the H5N1 virus is in rapid evolution (Webster et al. 2007b). These differences include direct transmission of H5N1 viruses from birds to humans, transmission predominantly via the respiratory route, increased thermal stability and varying pathogenicity in waterfowl.

Within the European Union, co-ordinated measures have been developed to prevent and control avian influenza in poultry. Influenza surveillance in both poultry and wild birds has been increased, and import bans are placed on susceptible imports from third countries with H5N1 outbreaks (European Commission 2007). Ireland has developed a range of relevant measures, including a contingency plan and ongoing risk assessments (DAFF 2009).

Detailed information has recently been prepared on Ireland's waterbirds (Crowe 2005). As yet, however, a review of this material has not been prepared, nor is information readily available of ecological factors that might be relevant to the introduction, maintenance, transmission 
and spread of infectious agents, such as the H5N1 avian influenza virus, between and within waterbird populations in Ireland. This paper seeks to address this issue. Particular emphasis is placed on five groups of wintering migrants (dabbling and sieving wildfowl, grazing wildfowl, diving wildfowl, waders and gulls), noting that the H5N1 avian influenza virus has mainly been isolated from this subset of the broader waterbird population (EFSA 2006; EFSA 2008).

\section{IRELAND'S WATERBIRDS}

\section{Overview}

Ireland is characterised by a diverse and large abundance of wetlands (Figure 1), making it attractive to a wide variety of waterbirds throughout the year. Wetlands are defined by the Ramsar Convention as areas of water, marsh, fen or peatland, whether natural or artificial, permanent or temporary, with water that is static or flowing, fresh, brackish or salt, including marine waters, the depth of which at low tide does not exceed six metres (Ramsar Convention Secretariat 2007).

Waterbirds are defined as all species which are ecologically dependent on such wetlands, and some 86 species are regularly recorded in Ireland (Table 1), many of which (34 species) occur year-round. However, very few of these are entirely resident. Few remain in Ireland throughout the year, with no immigration or emigration (the Mute Swan Cygnus olor is one.) Rather, the majority of the waterbirds which occur in Ireland are migratory, and are part of the East Atlantic Flyway (Figure 2), delimited by long-term studies of marked (ringed) birds (Wernham et al. 2002). This is a generalised picture of the distribution and movements of

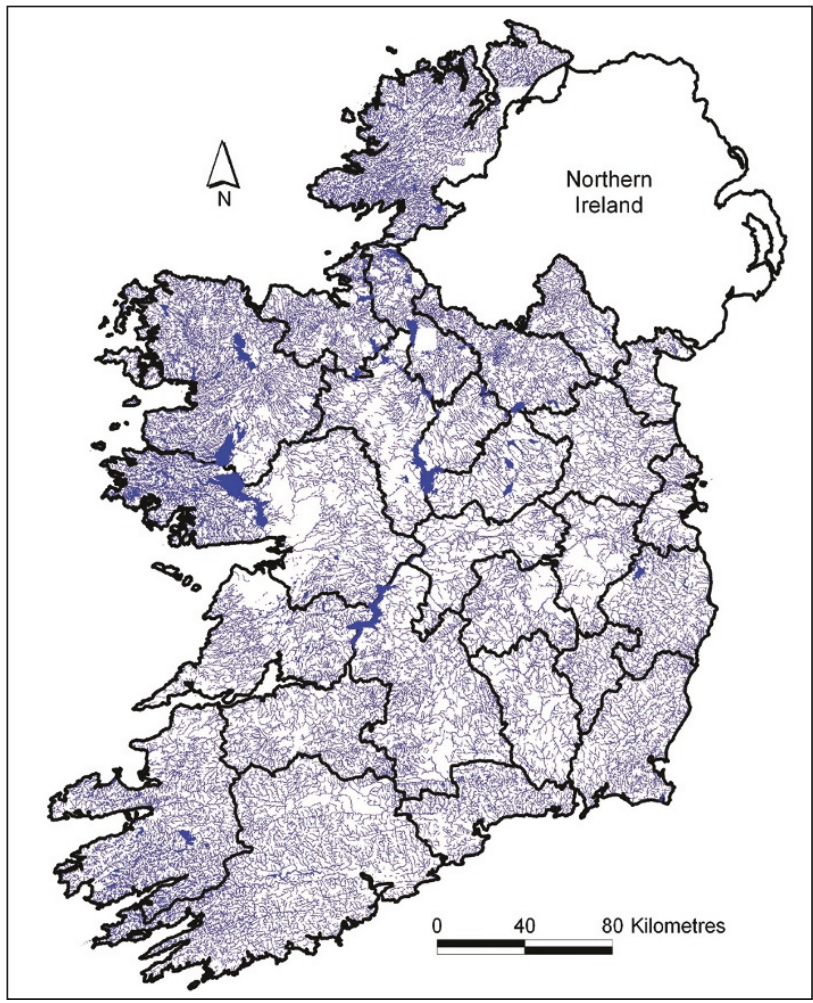

Figure 1: Ireland's wetlands, including rivers streams, reservoirs, ponds, lakes and canals.

migratory waterbirds and one which has particularly been derived from studies of waders. Details of international flyway delineation, as shown in Figure 2, are less applicable to other waterbird taxa (see Boere and Stroud 2006).

Migratory flyways

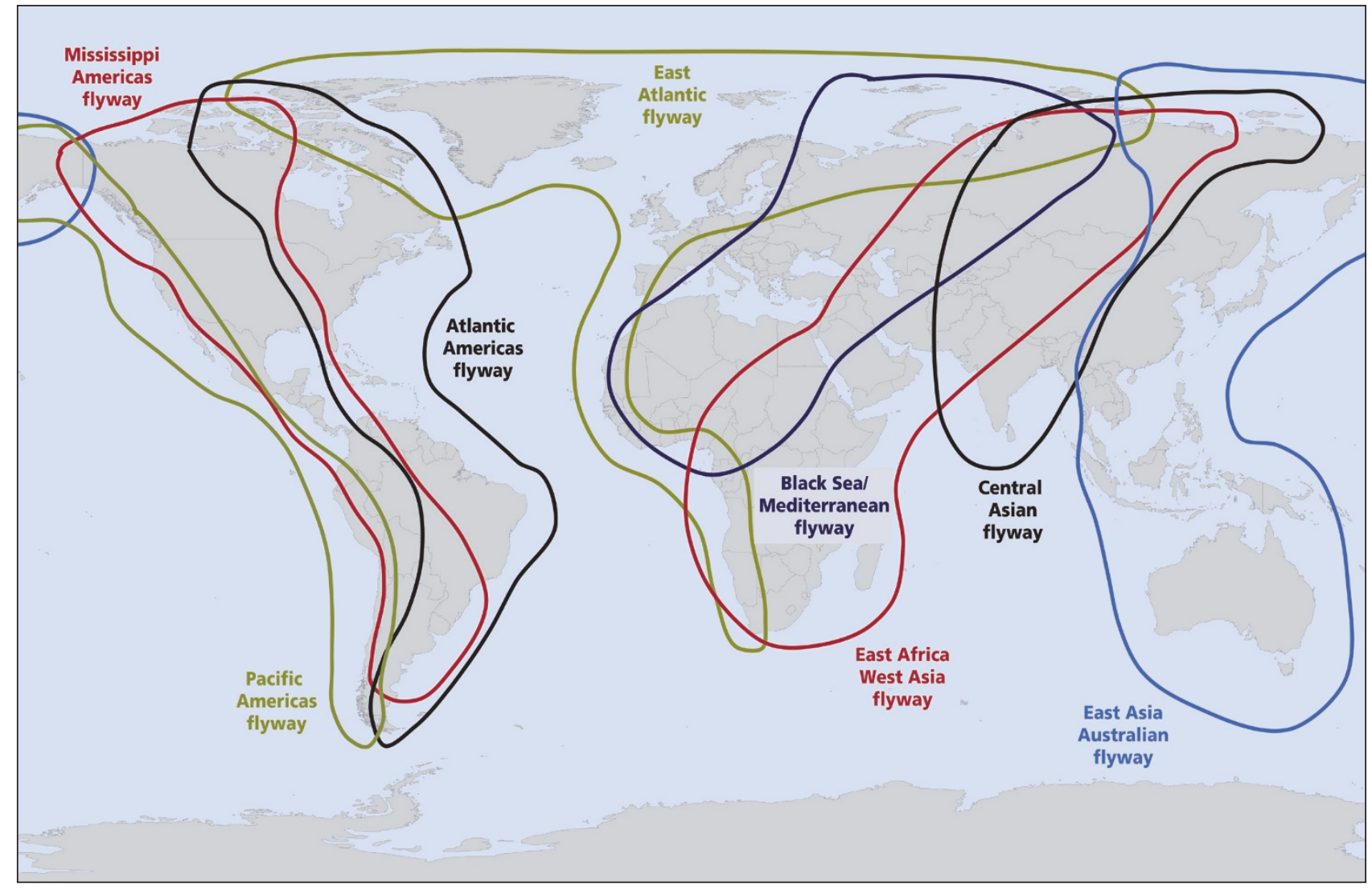

Figure 2: Wader flyways. Source: International Wader Study Group. 
Table 1: Waterbird species occurring in Ireland

\begin{tabular}{|c|c|c|}
\hline Species & & Occurrence in Ireland \\
\hline \multicolumn{3}{|l|}{ Divers and grebes } \\
\hline Red-throated Diver & Gavia stellata & Wintering - September to April, small numbers ( $<10 \mathrm{pr}$ ) breed in Donegal \\
\hline Black-throated Diver & Gavia arctica & Wintering - September to April (Scarce) \\
\hline Great Northern Diver & Gavia immer & Wintering - September to April \\
\hline Little Grebe & Tachybaptus ruficollis & Year-round \\
\hline Great Crested Grebe & Podiceps cristatus & Year-round, numbers increase during the winter due to immigrating birds \\
\hline \multicolumn{3}{|l|}{ Shearwaters and Petrels } \\
\hline Manx Shearwater & Puffinus puffinus & Breeding - March to August \\
\hline European Storm-petrel & Hydrobates pelagicus & Breeding - March to August \\
\hline Leach's Storm-petrel & Oceanodroma leucorhoa & Breeding - March to August and passage September to October \\
\hline Fulmar & Fulmarus glacialis & Year-round \\
\hline \multicolumn{3}{|l|}{ Gannet } \\
\hline Gannet & Morus bassana & Year-round \\
\hline \multicolumn{3}{|l|}{ Cormorants } \\
\hline European Shag & Phalacrocorax aristotelis & Year-round, few seen inshore outside the breeding season \\
\hline Cormorant & Phalacrocorax carbo & Year-round, some immigration during the winter \\
\hline \multicolumn{3}{|l|}{ Herons } \\
\hline Grey Heron & Ardea cinerea & Year-round \\
\hline Little Egret & Egretta garzetta & Year-round \\
\hline \multicolumn{3}{|l|}{ Wildfowl (swans, geese and ducks) } \\
\hline Mute Swan & Cygnus olor & Year-round \\
\hline Bewick's Swan & Cygnus columbianus & Wintering - October to April \\
\hline Whooper Swan & Cygnus cygnus & Wintering - October to April \\
\hline Greenland White-fronted Goose & Anser anser flavirostris & Wintering - October to April \\
\hline Greylag Goose & Anser anser & Year-round (feral birds), augmented by wintering birds- October to April \\
\hline Canada Goose & Branta canadensis & Year-round (feral birds) \\
\hline Barnacle Goose & Branta leucopsis & Wintering - October to April \\
\hline Light-bellied Brent Goose & Branta branta hrota & Wintering - October to April \\
\hline Shelduck & Tadorna tadorna & Wintering - September to April \\
\hline Wigeon & Anas penelope & Wintering - September to April \\
\hline Gadwall & Anas strepera & Year-round, augmented by wintering birds - October to April (scarce) \\
\hline Teal & Anas crecca & Year-round, augmented by wintering birds - September to April \\
\hline Mallard & Anas platyrhynchos & Year-round, augmented by wintering birds - September to April \\
\hline Pintail & Anas acuta & Wintering - September to April \\
\hline Shoveler & Anas clypeata & Wintering - September to April \\
\hline Pochard & Aythya ferina & Predominantly wintering - September to April, small numbers breed \\
\hline Tufted Duck & Aythya fuligula & Predominantly wintering - September to April, small numbers breed \\
\hline Scaup & Anas marila & Wintering - September to April \\
\hline Eider & Somateria mollissima & Wintering - September to April \\
\hline Long-tailed Duck & Clangula hyemalis & Wintering - September to April \\
\hline Common Scoter & Melanitta nigra & Predominantly wintering - September to April, small numbers breed \\
\hline Goldeneye & Bucephala clangula & Wintering - September to April \\
\hline
\end{tabular}




\begin{tabular}{|c|c|c|}
\hline Species & & Occurrence in Ireland \\
\hline Red-breasted Merganser & Mergus serrator & Wintering - September to April , small numbers breed in West \\
\hline Goosander & Mergus merganser & Year-round, small numbers breed (scarce) \\
\hline Ruddy Duck & Oxyura jamaicensis & Year-round (feral birds) \\
\hline \multicolumn{3}{|l|}{ Rail \& Coots } \\
\hline Water Rail & Rallus aquaticus & Year-round \\
\hline Moorhen & Gallinula chloropus & Year-round, augmented by wintering birds - September to April \\
\hline Coot & Fulica atra & Year-round, augmented by wintering birds - September to April \\
\hline \multicolumn{3}{|l|}{ Waders } \\
\hline Oystercatcher & Haematopus ostralegus & Year-round, augmented by wintering birds - September to April \\
\hline Ringed Plover & Charadrius hiaticula & Year-round, augmented by wintering birds - September to April \\
\hline Golden Plover & Pluvialis apricaria & $\begin{array}{l}\text { Wintering birds - September to April, breeding birds - April to September, some overlap } \\
\text { in populations }\end{array}$ \\
\hline Grey Plover & Pluvialis squatarola & Wintering birds - September to April \\
\hline Lapwing & Vanellus vanellus & $\begin{array}{l}\text { Wintering birds - September to April, breeding birds - April to September, some overlap } \\
\text { in populations }\end{array}$ \\
\hline Knot & Calidris canutus & Wintering birds - September to April \\
\hline Sanderling & Calidris alba & Wintering birds - September to April \\
\hline Little Stint & Calidris minuta & Passage birds - August to October (scarce) \\
\hline Curlew Sandpiper & Calidris ferruginea & Passage birds - August to October (scarce) \\
\hline Purple Sandpiper & Calidris maritima & Wintering birds - September to April \\
\hline Dunlin & Calidris alpina & Wintering birds - September to April, small numbers breed in west \\
\hline Ruff & Philomachus pugnax & Spring and autumn passage (scarce) \\
\hline Jack Snipe & Lymnocryptes minimus & Wintering birds - September to April \\
\hline Snipe & Gallinago gallinago & Year round, augmented by wintering birds - September to April \\
\hline Woodcock & Scolopax rusticola & Year round, augmented by wintering birds - September to April \\
\hline Black-tailed Godwit & Limosa limosa & Wintering birds - August to April \\
\hline Bar-tailed Godwit & Limosa lapponica & Wintering birds - September to April \\
\hline Whimbrel & Numenius phaeopus & Passage birds - April to September \\
\hline Curlew & Numenius arquata & Year round, augmented by wintering birds - September to April \\
\hline Redshank & Tringa totanus & Year round, augmented by wintering birds - September to April \\
\hline Greenshank & Tringa nebularia & Wintering birds - September to April \\
\hline Common Sandpiper & Actitus hypoleucos & Summer visitor- breeding birds present April to September \\
\hline Turnstone & Arenaria interpres & Wintering birds- September to April \\
\hline \multicolumn{3}{|l|}{ Skuas, Gulls \& Terns } \\
\hline Great Skua & Stercorarius skua & Passage birds - April to October \\
\hline Arctic Skua & S. parasiticus & Passage birds - April to October \\
\hline Mediterranean Gull & Larus melanocephalus & Year-round, very small breeding numbers (scarce) \\
\hline Black-headed Gull & Larus ridibundus & Year-round, some local migration to/from breeding areas \\
\hline Common Gull & Larus canus & Year-round, some local migration to/from breeding areas in west. \\
\hline Lesser Black-backed Gull & Larus fuscus & Occur during the breeding season, March/April to August/September \\
\hline Herring Gull & Larus argentatus & Year-round, some local migration \\
\hline Great Black-backed Gull & Larus marinus & Year-round, some local migration \\
\hline Little Gull & Larus minutus & Wintering birds - September to April (scarce) \\
\hline
\end{tabular}


The concept of a flyway is based on the migratory behaviour of birds. Flyways in northwestern Europe are typically north-south in orientation, with migratory birds moving to warmer clines during the autumn, and then returning during the spring to more northerly breeding areas. Many species migrate along well-defined routes, and consistently use the same sites as stop-over and/or wintering sites.

Some eight general migratory flyways have been defined (Davidson and Pienkowski 1987). The East Atlantic Flyway (Figure 2) extends from east Canada, across northern Europe to west Siberia in the north, and also south along the east Atlantic shores of northwest Europe and west Africa. Most migratory waterbird species which occur in Ireland during the winter have originated from one or more of the following areas:

- North/ northwest: Canada, Greenland and Iceland;
- Northeast: the Netherlands, Denmark, Germany, Fennoscandia, the Baltic, western Russia (west of the Ural Mountains);

- Far-eastern: Russia east of the Ural Mountains and Siberia; and,

- Central/ east Europe: Europe east of and including Poland, Czech Republic and Austria.

The breeding origins of waterbird species occurring in Ireland during the winter are summarised in Table 2. Most migratory waterbird species which breed in Ireland winter further south, in Continental Europe or west Africa (i.e., they belong to the same principal flyway).

\section{Migrants}

a. Breeding migrants

During the spring and summer months, hundreds of thousands of waterbirds come to Ireland to breed,

Table 2: Flyway origins of species occurring in Ireland outside the breeding season

\begin{tabular}{|c|c|c|c|c|c|}
\hline \multicolumn{2}{|l|}{ Species } & \multirow{2}{*}{$\begin{array}{l}\text { Breeding }{ }^{1} \\
\text { Arctic/ boreal W Eurasia, } \\
\text { Greenland }\end{array}$} & \multirow{2}{*}{$\begin{array}{l}\text { Wintering }{ }^{1} \\
\text { Europe, Greenland }\end{array}$} & \multirow{2}{*}{$\begin{array}{l}\text { Flyway estimate }{ }^{2} \\
300,000\end{array}$} & \multirow{2}{*}{$\begin{array}{l}\text { All-Ireland estimate }{ }^{3} \\
1,025+\end{array}$} \\
\hline Red-throated Diver & Gavia stellata & & & & \\
\hline Black-throated Diver & Gavia arctica & N Europe and W Siberia & $\begin{array}{l}\text { NW Europe, Mediterranean, } \\
\text { Black and Caspian Seas }\end{array}$ & 375,000 & $<1,000$ \\
\hline Great Northern Diver & Gavia immer & N America, Greenland, Iceland & NW Europe & 5,000 & $<1,000$ \\
\hline Little Grebe & Tachybaptus ruficollis & Europe, NW Africa & Europe, NW Africa & 340,000 & $2,345+$ \\
\hline Great Crested Grebe & Podiceps cristatus & NW Europe & NW Europe & 475,000 & $5,385+$ \\
\hline Great Cormorant & Phalacrocorax carbo & NW Europe & NW Europe & 120,000 & $13,710+$ \\
\hline Grey Heron & Ardea cinerea & W Europe, NW Africa & W Europe, NW Africa & 274,500 & $2,960+$ \\
\hline Little Egret & Egretta garzetta & Ireland, UK, Continent, N Africa & Ireland, UK, Continent, N Africa & 134,000 & $<1,000$ \\
\hline Mute Swan & Cygnus olor & Irelanda & Ireland $^{a}$ & $11,440 a$ & 11,440 \\
\hline Bewick's Swan & $\begin{array}{l}\text { Cygnus columbianus } \\
\text { bewickii }\end{array}$ & Arctic N Russia & NW Europe & 29,000 & 380 \\
\hline Whooper Swan & Cygnus cygnus & Iceland & Ireland, UK, Iceland & 20,900 & 12,730 \\
\hline $\begin{array}{l}\text { Greenland White- } \\
\text { fronted Goose }\end{array}$ & $\begin{array}{l}\text { Anser albifrons } \\
\text { flavirostris }\end{array}$ & W Greenland & Scotland, Ireland & 33,000 & 11,340 \\
\hline Greylag Goose & Anser anser & Iceland & UK, Ireland & 89,100 & $5,030^{b}$ \\
\hline Canada Goose & Branta canadensis & Ireland & Ireland & 1,050 & 1,050 \\
\hline Barnacle Goose & Branta leucopsis & Greenland & Scotland, Ireland & 54,100 & 9,035 \\
\hline $\begin{array}{l}\text { Light-bellied Brent } \\
\text { Goose }\end{array}$ & Branta bernicla hrota & Canada, Greenland & Ireland & 21,750 & 30,000 \\
\hline Common Shelduck & Tadorna tadorna & NW Europe & NW Europe & 300,000 & 14,610 \\
\hline Eurasian Wigeon & Anas penelope & W Siberia, NW and NE Europe & NW Europe & $1,500,000$ & $82,370+$ \\
\hline Gadwall & Anas strepera & NW Europe & W Europe & 60,000 & 630 \\
\hline Eurasian Teal & Anas crecca & $\mathrm{N}$ and NW Europe & NW Europe & 400,000 & $45,010+$ \\
\hline Mallard & Anas platyrhynchos & N Europe & NW Europe & $4,500,000$ & $38,250+$ \\
\hline Northern Pintail & Anas acuta & N Europe, W Siberia & NW Europe & 60,000 & 1,235 \\
\hline Northern Shoveler & Anas clypeata & N, NW, Central Europe & NW, Central Europe & 40,000 & 2,545 \\
\hline Common Pochard & Aythya ferina & Russia, NE and NW Europe & NE and NW Europe & 350,000 & 37,780 \\
\hline Tufted Duck & Aythya fuligula & $\mathrm{N}$ and NW Europe & NW Europe & $1,200,000$ & 36,610 \\
\hline Greater Scaup & Aythya marila & W Siberia, N Europe & W Europe & 310,000 & 4,430 \\
\hline
\end{tabular}




\begin{tabular}{|c|c|c|c|c|c|}
\hline \multicolumn{2}{|l|}{ Species } & \multirow{2}{*}{$\begin{array}{l}\text { Breeding } 1 \\
\text { see } \mathrm{c} \text { below }\end{array}$} & \multirow{2}{*}{$\begin{array}{l}\text { Wintering }{ }^{1} \\
\text { see c below }\end{array}$} & \multirow{2}{*}{$\begin{array}{l}\text { Flyway estimate }{ }^{2} \\
1,548,000 \mathrm{c}\end{array}$} & \multirow{2}{*}{$\begin{array}{l}\text { All-Ireland estimate }{ }^{3} \\
2,890\end{array}$} \\
\hline Common Eider & Somateria mollissima & & & & \\
\hline Long-tailed Duck & Clangula hyemalis & Iceland and Greenland & N Atlantic & 125,000 & $<1,000$ \\
\hline Common Scoter & Melanitta nigra & N and NW Europe, W Siberia & Baltic, E Atlantic & $1,600,000$ & 23,190 \\
\hline Common Goldeneye & Bucephala clangula & N, NW and Central Europe & NW and Central Europe & 400,000 & 9,665 \\
\hline $\begin{array}{l}\text { Red-breasted } \\
\text { Merganser }\end{array}$ & Mergus serrator & $\begin{array}{l}\text { NW and Central Europe, } \\
\text { Iceland, E Greenland }\end{array}$ & NW and Central Europe, Iceland & 170,000 & 3,390 \\
\hline Water Rail & Rallus aquaticus & Iceland & Faeroes, Scotland, Ireland & Unknown & Unknown \\
\hline Common Moorhen & Gallinula chloropus & Europe and N Africa & Europe and N Africa & $3,550,000$ & Unknown \\
\hline Common Coot & Fulica atra & E, N, W Europe & NW Europe & $1,750,000$ & 33,160 \\
\hline $\begin{array}{l}\text { Eurasian } \\
\text { Oystercatcher }\end{array}$ & $\begin{array}{l}\text { Haematopus } \\
\text { ostralegus }\end{array}$ & N, C, W Europe & Europe, NW Africa & $1,020,000$ & 67,620 \\
\hline Ringed Plover & Charadrius hiaticula & Iceland, N and NW Europe & $\begin{array}{l}\text { W Europe, N Africa, } \\
\text { Mediterranean }\end{array}$ & 73,000 & 14,580 \\
\hline $\begin{array}{l}\text { European Golden } \\
\text { Plover }\end{array}$ & Pluvialis apricaria & Iceland, the Faeroes, Greenland & $\begin{array}{l}\text { Ireland, W Britain, Continent, } \\
\text { NW Africa }\end{array}$ & 930,000 & $166,700+$ \\
\hline Grey Plover & Pluvialis squatarola & Arctic Russia, NE Canada & $\begin{array}{l}\text { Wadden Sea, Ireland, UK, S and } \\
\text { W Africa }\end{array}$ & 247,000 & 6,315 \\
\hline Northern Lapwing & Vanellus vanellus & Europe & Europe, N Africa & $6,750,000$ & $207,700+$ \\
\hline Red Knot & Calidris canutus & Canada, Greenland & W Europe & 450,000 & 18,970 \\
\hline Sanderling & Calidris alba & NE Canada, Greenland, Svalbard & E Atlantic, W and S Africa & 123,000 & 6,680 \\
\hline Purple Sandpiper & Calidris maritima & E Atlantic & E Atlantic & 75,000 & 3,330 \\
\hline Dunlin & Calidris alpina & $\begin{array}{l}\text { N Scandinavia, Russia, NW } \\
\text { Siberia }\end{array}$ & $\begin{array}{l}\text { W Europe, Mediterranean, N } \\
\text { Africa }\end{array}$ & $1,330,000$ & 88,480 \\
\hline Jack Snipe & Lymnocryptes minimus & $\begin{array}{l}\text { N Russia, S Sweden, N Poland, } \\
\text { N Belarus, Baltic }\end{array}$ & W and $S$ Europe, $N$ and W Africa & $>1,000,000$ & Unknown \\
\hline Snipe & Gallinago gallinago & N Europe & $S$ and W Europe, W Africa & $>2,500,000$ & Unknown \\
\hline Woodcock & Scolopax rusticola & Europe & W and $S$ Europe, $N$ Africa & $17,500,000$ & Unknown \\
\hline Black-tailed Godwit & Limosa limosa & Iceland, the Faeroes & $\begin{array}{l}\text { Britain, Ireland, Continent, N } \\
\text { Africa }\end{array}$ & 47,000 & 13,880 \\
\hline Bar-tailed Godwit & Limosa lapponica & N Europe, N Russia & W Europe, NW Africa & 120,000 & 16,280 \\
\hline Whimbrel & Numenius phaeopus & Iceland, the Faeroes, Scotland & W Africa & 675,000 & Unknown \\
\hline Eurasian Curlew & Numenius arquata & $\mathrm{W}, \mathrm{N}$ and Central Europe & $\begin{array}{l}\text { W Europe, Mediterranean, NW } \\
\text { Africa }\end{array}$ & 850,000 & $54,650+$ \\
\hline Common Redshank & Tringa totanus & see $\mathrm{d}$ below & see $\mathrm{d}$ below & $400,000 d$ & 31,090 \\
\hline Common Greenshank & Tringa nebularia & Scotland, Scandinavia & $\begin{array}{l}\text { W and SW Europe, NW, W and } \\
\text { S Africa }\end{array}$ & 420,000 & 1,265 \\
\hline Ruddy Turnstone & Arenaria interpres & NE Canada, Greenland & W Europe, NW Africa & 150,000 & 11,810 \\
\hline Mediterranean Gull & Larus melanocephalus & Black Sea, C, S, W Europe & $\begin{array}{l}\text { Black Sea, Mediterranean, NW } \\
\text { Europe, NW Africa }\end{array}$ & 660,000 & $<200$ \\
\hline Black-headed Gull & Larus ridibundus & Greenland, $\mathrm{N}$ and $\mathrm{W}$ Europe & $S$ and W Europe & $4,250,000$ & Unknown \\
\hline Common Gull & Larus canus & Iceland, Ireland, Britain & Europe, N Africa & $1,725,000$ & Unknown \\
\hline $\begin{array}{l}\text { Lesser Black-backed } \\
\text { Gull }\end{array}$ & Larus fuscus & $\begin{array}{l}\text { Greenland, Iceland, Ireland, UK, } \\
\text { Belgium, France }\end{array}$ & W Europe, W France & 550,000 & Unknown \\
\hline Herring Gull & Larus argentatus & $\begin{array}{l}\text { Iceland, Ireland, Britain, NW } \\
\text { France, Germany }\end{array}$ & NW Europe & 590,000 & Unknown \\
\hline $\begin{array}{l}\text { Great Black-backed } \\
\text { Gull }\end{array}$ & Larus marinus & $\begin{array}{l}\text { NW France, Britain, Ireland, } \\
\text { Iceland, N Europe }\end{array}$ & E Atlantic S to Iberia & 440,000 & Unknown \\
\hline
\end{tabular}

${ }^{1}$ From Wernham et al. (2002), also EURING's Migration Mapping Tool (http://blx1.bto.org/ai-eu)

${ }^{2}$ From Wetlands International (2002).

${ }^{3}$ Crowe et al. (2008).

a The Irish Mute Swan population has been elevated to biogeographic population (Wetlands International 2002), and the threshold is thus the same as that for all-Ireland.

${ }^{\mathrm{b}}$ Additional birds from feral population - c. 2,000 individuals.
${ }^{\mathrm{C}}$ The relevant population on which to base the $1 \%$ threshold for Common Eider has been taken as the NW European total which comprises the four populations in this region (Britain/Ireland 73,000, Baltic/ Wadden Sea 850,000-1,200,000, Norway/NW Russia 300,000-550,000 and White Sea 20,000-30,000). ${ }^{d}$ The relevant populations for Common Redshank include two populations, robusta (breed in Iceland and the Faeroes, winter Britain, Ireland, NW France) and brittanica (breed in Britain and Ireland, winter Britain, Ireland, NW France). 
predominantly from southern latitudes. These breeding migrants begin to arrive in Ireland in March, and are present in highest numbers between April and August, with some individuals remaining into early October. These waterbirds breed predominantly around Ireland's coastline, colonising the cliffs and islands. Some also nest inland, on lake islands and along the shorelines of lakes, rivers and streams. The breeding migrants include seabirds (petrels and shearwaters, Gannet Morus bassana, cormorants, gulls, terns and auks), as well as a number of other species/groups such as Red-throated Diver Gavia stellata, grebes, herons, swans, feral geese, ducks, rails, coots, waders, Great Skua, gulls, terns and auks.

b. Wintering migrants

During the autumn and winter, Ireland's mild winter climate, relative to most other European countries, together with its diversity of wetlands, make it attractive over a million northern and boreal-nesting migrant waterbirds. Therefore, most of the wintering, or non-breeding, migrants come from northern latitudes from Canada in the west to Taimyr in arctic Russia in the east. These birds begin to arrive from as early as July, with most occurring in Ireland between September and February, and some individuals remaining into early May. They occur in largest numbers of coastal estuaries, and on a selection of inland lakes, such as Lough Neagh in Northern Ireland and Lough Corrib in Co. Galway. Wintering waterbirds include fewer bird groups (divers, grebes, herons, swans, geese, ducks, rails, coots, waders and gulls), but a much broader diversity of species within these groups compared with breeding.

\section{Residents}

Many waterbirds remain in Ireland year-round. These include grebes, cormorants, herons, Mute Swan, some duck species and some gulls. However, as mentioned above, Mute Swan is one of very few examples of an entirely resident species, remaining in Ireland throughout the year with no immigration or emigration. Most other species are joined by additional birds during the autumn and winter months migrating from arctic and boreal-nesting areas (see section on migrants below).

Ireland also supports a number of introduced waterbirds, which remain relatively local throughout the year. These include:

Naturalised introductions: Some wildfowl species have escaped from collections, and are free-living (e.g. Greylag Goose Anser anser and Canada Goose Branta canadensis). While these birds are sedentary, and do not generally move large distances, they cannot be easily distinguished from their wild counterparts;

- Wildfowl bred for hunting: Large numbers of Mallard Anas platyrhynchos are farmed, and released during the autumn for hunting; and,

- Domestic wildfowl: This group includes farmyard geese and ducks, and birds from wildfowl collections. Some of the farmyard geese and ducks have interbred with naturalised Greylag and Mallard respectively, and are part of the feral populations described above.

\section{Interactions between populations}

Most waterbirds occurring in Ireland come from more than one population. For example, small numbers of Coot (almost 4,000 pairs) breed in Ireland (Gibbons et al. 1993), while wintering numbers exceed 33,000 individuals (Crowe et al. 2008). It is believed that the breeding birds are resident, and that during the winter, Britain and Ireland receive large numbers of immigrating birds from northern Europe, Scandinavia and the Baltic (Wernham et al. 2002). There are many other similar examples where numbers of resident breeding birds are augmented by winter migrants of the same species, e.g. Great Crested Grebe Podiceps cristatus, Teal Anas crecca, Moorhen Gallinula chloropus and Oystercatcher Haematopus ostralegus (Table 1).

Some breeding seabird species, such as Kittiwake Rissa tridactyla, become oceanic in nature outside the breeding season, when they are seldom recorded in inshore waters. Other species are entirely migratory; the five tern species and Common Sandpiper Actitus hypoleucos occur during the breeding period only, while most of the other wader species occur on passage and/or during the winter. For some species, many distinct groups have been recognised, and discrete populations have been defined, some of which have been split taxonomically into subspecies. For example, there are three populations of Dunlin Calidris alpina which occur in Ireland. Calidris alpina schinzii breeds in Ireland and winters further south in southwest Europe and northwest Africa, C. a. arctica breeds in Greenland and occurs in Ireland during spring and autumn on passage, while C. a. alpina breeds in Scandinavia and Siberia and winters in Ireland (Stroud et al. 2004). Other species, such as Golden Plover Pluvialis apricaria, breed and winter in Ireland, although the origins of the respective populations differ; Irish-breeding birds move south to winter, while the non-breeding birds come from the population breeding in Iceland and the Faeroes. Further details, including the latin names and the status, of all waterbirds occurring in Ireland are presented in Table $\mathbf{1}$

Furthermore, there are periods (between March and early May and later between July and October) when there is considerable mixing of breeding and wintering (nonbreeding) migrants (Figure 3). Waterbirds of varying origins regularly occur together. Examples include:

- Close to 10,000 post-breeding terns congregate in Dublin Bay in August and September prior to their southward migration and mix with thousands of migrant geese, waders and gulls arriving from faraway arctic breeding grounds; and,

- Large numbers of Icelandic-breeding Greylag Geese (roughly 2,000 birds) mix with a resident flock of 800 feral Greylag Geese at Lough Swilly each winter.

Interactions between species

Outside the breeding season, most waterbirds are highly gregarious, and generally assemble in large, and often mixed-species flocks. By doing so, they reduce their risk to predation, as a flock of birds is more likely to detect a predator than a single bird. Flocks of swans and geese 
often include family parties which tend to remain intact for most of the first year. Although preferred wetlands among different waterbird groups (dabbling ducks, swans etc; see below) is to some extent exclusive, some of the larger wetland complexes include a variety of habitat types, and may support many different groups. For example, Lough Derg in counties Tipperary, Galway and Clare supports significant concentrations of a range of both dabbling and diving wildfowl, as well as waders and gulls. Further, waterbird species tend to gather together in mixed flocks where their favoured food is available.

During the breeding period itself, most species tend to nest either solitarily, with many pairs holding and defending territories (e.g. Lapwing), or in dense colonies, where birds nest in close proximity, usually on cliffs and/ or on islands, where they afford greater protection from predation and disturbance. It is not unusual for colonial species to nest in mixed-species colonies.

\section{IRELAND'S WINTERING WATERBIRDS}

\section{Wintering waterbird surveys}

Wintering waterbirds in the Republic of Ireland have been monitored for almost 40 years as part of three main surveys, the Wetlands Enquiry (1971/72-1973/74) (Hutchinson 1979), the Winter Wetlands Survey (1984/851986/87) (Sheppard 1993) and the Irish Wetland Bird Survey (I-WeBS 1994/95-present) (Crowe 2005). In most cases, parallel surveys have been carried out in Northern Ireland, with the most recent, the Wetland Bird Survey (WeBS), in operation since 1993/94. An example of information generated from I-WeBS (specifically, the distribution and abundance of Mallard, Anas platyrhynchos) is presented in Figure 4. These surveys have served to highlight the importance of wetlands in Ireland for wintering waterbirds, and have defined a suite of wetlands which have proven of significance, many of which have since been designated as Special Protection Areas (SPAs) under the EU Birds Directive (EEC/79/409) (European Commission 2006). To this end, waterbird populations, and the wetlands upon which they rely, continue to be monitored in Ireland through I-WeBS and WeBS.

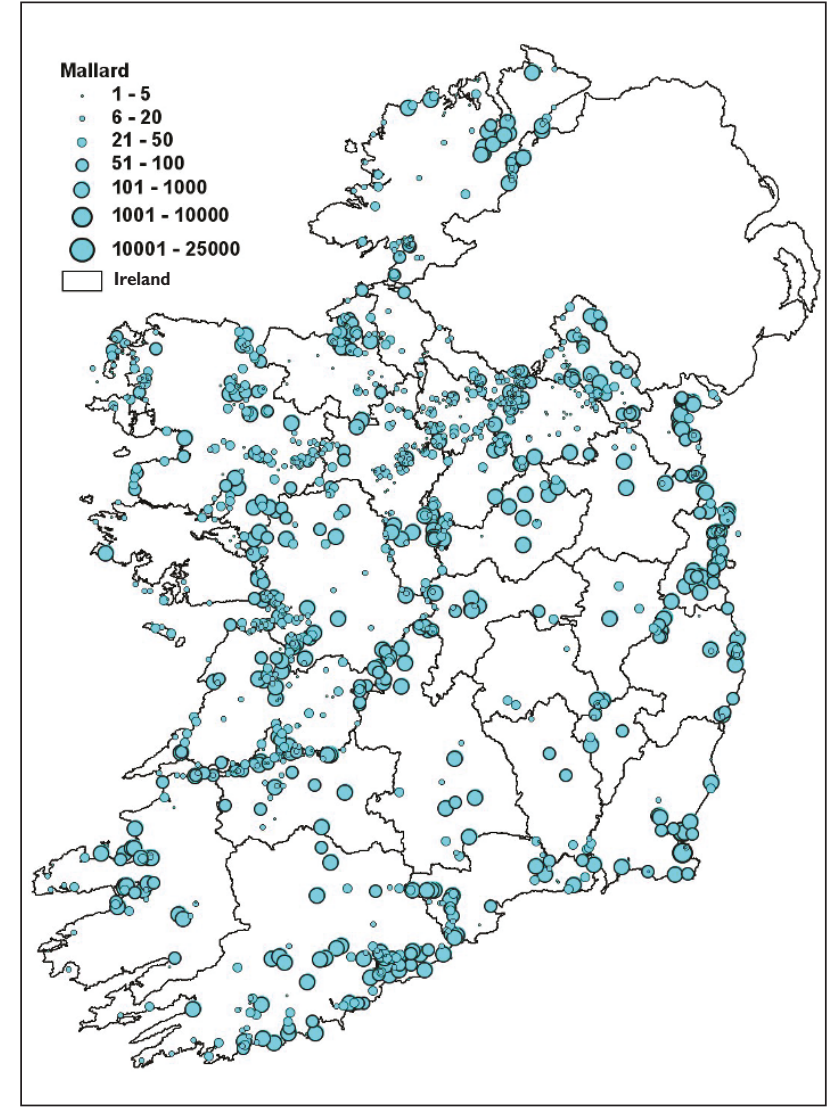

Figure 4: Distribution and abundance of mallard (Anas platyrhynchos) in Ireland. These data were collected by BirdWatch Ireland as part of the Irish Wetland Bird Survey. The counts were conducted over the last 10 years, mainly from September to March. At each sampling site, the circle represents the maximum number of mallard supported, based on the maximum number observed at each of the recording sites on a single occasion during the last 10 years.

\section{Within-winter movements}

Many waterbird species are highly site-faithful, returning to the same wintering areas each year. While most species are entirely dependent on wetland habitat, others can be found considerable distances from wetland sites. Swans, geese, and some wader species are regularly seen feeding on grassland and/or stubble, and use wetland habitats only for roosting.

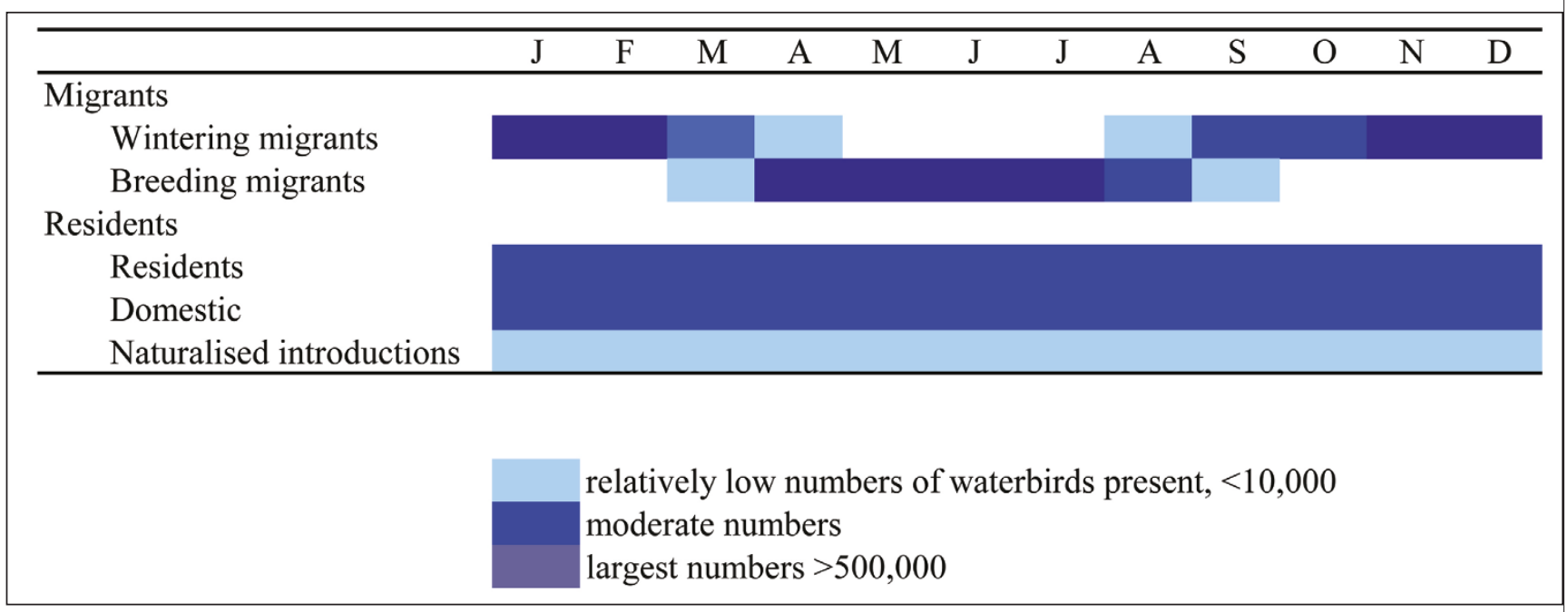

Figure 3: The number of migrant and resident waterbird present in Ireland throughout the year. 
During the course of the winter, there is regular temporal and spatial movement of waterbird species. Along the coast, roosting and feeding is largely dictated by tide. Many swan and goose species feed by day, and often fly large distances (occasionally in excess of $20 \mathrm{~km}$ ) to their wetland roosts at night. Many duck and wader species feed by night as well as by day. The roosting and feeding locations and patterns of movements of these waterbird species are less defined.

Large-scale movements of waterbirds between wetland sites have been directly related to weather conditions. There is a noticeable decline in some waterbirds during early autumn, particularly resident species such as Little Grebe, Cormorant and Mallard. It is thought that this reflects a shift in range of these species as they begin to disperse from coastal sites to exploit small inland wetlands that are replenished by increasing rainfall levels. In contrast, during cold weather periods, when such small wetlands are more likely to become frozen over, there is reversal of this movement, as species are forced at times to move large distances to larger waterbodies, riverine sites or to coastal sites, all which are less likely to become frozen.

During particularly cold weather periods in Europe, a number of species from northern Europe, and even Britain, are known to move west into Ireland, with its milder climate (Ridgill and Fox 1990). It is known that Lapwing and Golden Plover are particularly sensitive to such cold weather periods, when numbers in Ireland have been seen to increase dramatically. In extreme situations, Wigeon and Teal in Britain and Ireland move further south into France and Iberia. Here, it is known that there is some mixing with other populations breeding on the Black and Mediterranean Seas.

\section{Waterbird species}

Waterbirds are highly variable in size and shape, and have adopted a wide range of techniques that enable them to successfully exploit the variety of food types provided by wetland habitats. In general, wildfowl species feed by dabbling, sieving, diving (for example, to obtain benthic food items, or to prey on fish) and/or grazing, waders by probing or surface pecking, and gulls by surface pecking. Many species exhibit more than one method of feeding. For example, most dabbling ducks are also capable of diving, but do so for much shorter periods of time. Wintering waterbirds can be divided into three main groups:

- Wildfowl include swans, geese and ducks, and are also often accompanied by their 'allies', the divers, grebes, rails, as well as Cormorant, Little Egret and Grey Heron;

- Waders frequent intertidal flats and shallow water, especially along coastal sites. This group comprises oystercatcher, plovers, lapwings, sandpipers, curlews and woodcocks; and,

- Gulls include the large family of seabirds that occupy a wide variety of wetland and non-wetland habitats. Some gull species have learned to co-exist successfully with man and have thrived in human habitats.

Terns are summer migrants, and mostly occur on passage during the autumn and spring months only, and are very seldom recorded during mid-winter.

Almost 140 waterbird species have been recorded during I-WeBS and WeBS. However, this total includes many vagrant species, which for a variety of reasons have strayed away from their

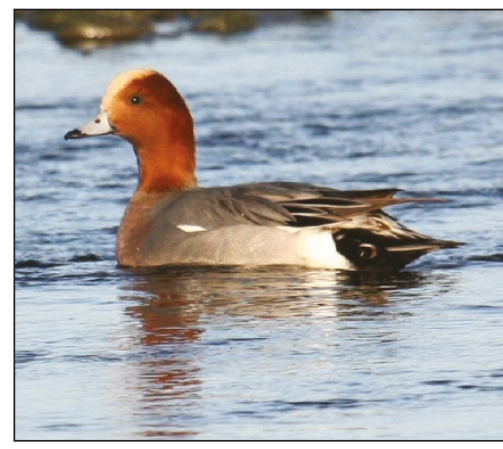

Figure 5: (Eurasian) Wigeon (Anas penelope). Photo: Ronnie Martin.

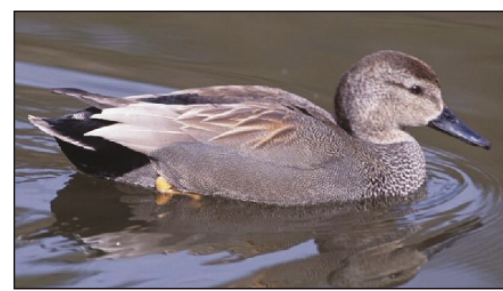

Figure 6: Gadwell (Anas strepera). Photo: Eddie Dunne.

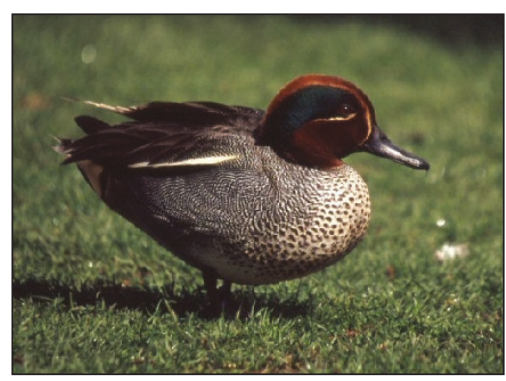

Figure 7: Teal

(Anas crecca). Photographer: John Carey.

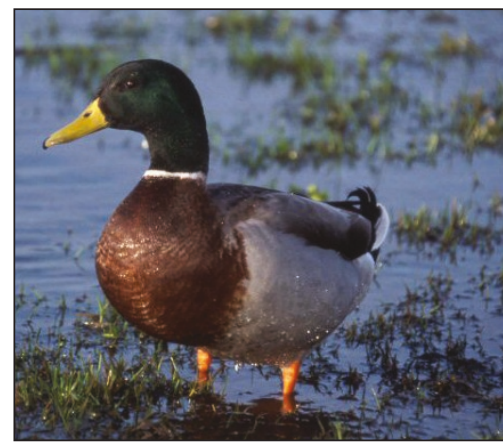

Figure 8: Mallard (Anas platyrhynchos). Photo: John Carey.

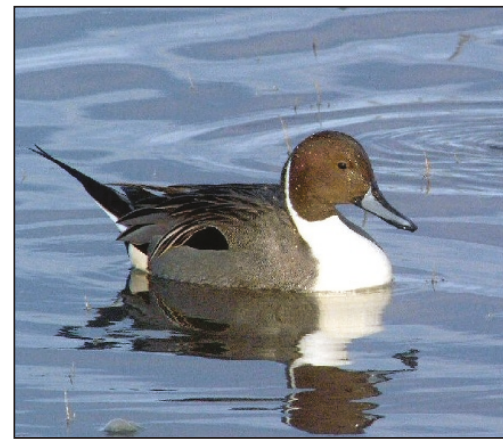

Figure 9: (Northern) Pintail (Anas acuta). Photo: Michael Finn.

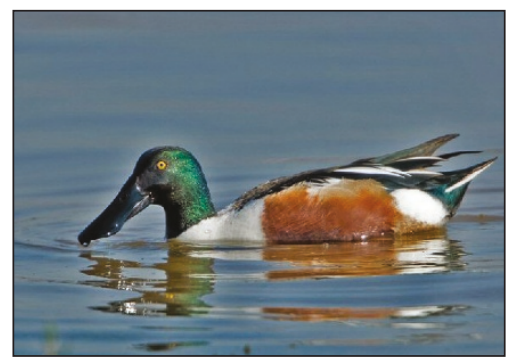

Figure 10: (Northern) Shoveler (Anas clypeata). Photo: Ken Kinsella. 
usual flyways. More regularly, some 58 species occur in significant numbers at a variety of sites in Ireland, including 33 wildfowl, 20 wader and five gull species.

\section{a. Dabbling and sieving wildfowl}

Distribution and feeding habits

Dabbling is the preferred technique, which has given a large group of duck species their collective name. Dabbling ducks in Ireland include Shelduck, Wigeon, Gadwall, Teal, Mallard, Pintail and Shoveler (Figure 5-10). This technique is also employed by other species, particularly swans. Dabbling species feed mostly on seeds or invertebrate prey present on the surface of the water. They access food at slightly greater depths by dipping their heads and necks below the water. The long necks of swans allow them to access deeper food items than the ducks. These species can all extend their reach by up-ending into a vertical position, with their tails pointed in the air. Virtually all species which dabble feed by pecking at individual items. However, the dabbling ducks can also feed by sieving dense concentrations of smaller food, where they suck in water through a slightly open bill, and filter out the food items as the water is then expelled out at the sides. With the exception of Shelduck, which is exclusively coastally distributed, most dabbling species occur on a variety of relatively shallow wetlands, both inland and coastal. Dabbling species are often recorded on the lee shore, where the wind has blown seeds and invertebrates into a relatively narrow band. Temporary flooded fields are particularly attractive, where abundant food items surface from the soil or pasture. Wigeon, Gadwall, Teal and Mallard, in particular, are regularly seen taking advantage of such food resources. They are widely distributed throughout the country.

\section{Social interactions}

Dabbling species are regularly recorded feeding together in large, and usually mixed, flocks, each species exploiting different feeding niches. Some species gain added benefit by feeding communally. Shoveler are often recorded feeding closely to the tail of the bird in front. The combined action of paddling feet is particularly effective in stirring up the water and increasing the amount of food brought to the surface. Wigeon regularly feed alongside swans and Coot, and parasitise them as they return to the surface with food. Gadwall have also been recorded feeding on aquatic plants brought to the surface by diving Coot and Goldeneye.

\section{b. Grazing wildfowl}

Distribution and feeding habits

Whooper and Bewick's Swans, Greenland White-fronted, Greylag, Barnacle and Light-bellied Brent Geese and Wigeon

(Figure 5) are all grazing species. The swans and first two species of goose listed also feed on stubble. Light-bellied Brent Goose and Wigeon spend the autumn and early part of the winter grazing coastal vegetation (particularly Zostera spp. (eelgrass), Enteromorpha spp. and Ulvae sp. [green algae]), and move to feed on grasslands once these coastal supplies have become depleted. Most swans and Wigeon, tend to remain close to water at all times, while the remaining species listed above may be found considerable distances from wetlands. All of these species return to roost by night on wetlands.

Whooper Swan and Wigeon are the most widely distributed species of this group, found grazing next to wetlands in almost all counties. Greenland White-fronted Geese are largely concentrated in Wexford Harbour, in particular on the Slobs, though small numbers also occur at approximately 30 locations elsewhere in the country. The range of migratory (Icelandic) Greylag Goose is also quite restricted, and just six flocks are recognised in the Republic. However, the introduced population of this species is much more widespread, and small numbers occur throughout the country, and throughout the year. Barnacle and Light-bellied Brent Geese remain along the coast throughout the winter period. The former species is distributed mostly on the islands along the west and northwest coast of Ireland, where it feeds predominantly on grasslands. Light-bellied Brent Geese occur on estuaries along the east, south and southwest coasts, and increasingly use coastal grasslands as the winter progresses. Wigeon also feed on grassland, but are restricted to those adjoining wetlands, for security (Figure 11).

\section{Social interactions}

While these species tend to mix while in wetlands (as described in 'Dabbling species' above), the majority tend to assemble in single-species flocks while grazing. This is, most likely, due to differences in range, and also preferred feeding times during the day. However, mixed-species flocks do occur. For example, Wigeon and Light-bellied Brent Goose associate at some sites, though mostly when feeding on coastal vegetation. The diets of Light-bellied Brent Geese and Black-tailed Godwits (see 'Waders' below) are markedly different, though they are often seen feeding together.

\section{c. Diving wildfowl}

Distribution and feeding habits

Diving species forage by diving in an area, and seek food either visually, or by touch. They feed on submerged aquatic vegetation, or on animal prey, particularly molluscs and crustaceans and/or fish. The list of diving species in Ireland is quite extensive, and includes the divers, grebes, Cormorant, Pochard, Tufted Duck, Scaup, Eider, Longtailed Duck, Common Scoter, Goldeneye, and Red-breasted Merganser, Moorhen and Coot. Some of the species listed above are largely marine, and are seldom seen close to shore during the winter. These include the divers, Eider, Long-tailed Duck, Common Scoter and Red-breasted Merganser. All remaining species, with the exception of Scaup, which occurs predominantly along the coast and on a few select inland sites, are widely distributed, especially on large deep wetlands. Great-crested Grebe, Little Grebe, Cormorant and Goldeneye are found on a variety of both 


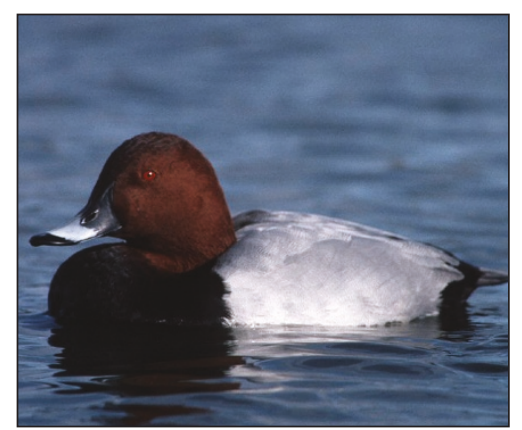

Figure 11: Pochard (Aythya ferina). Photo: Billy Clarke.

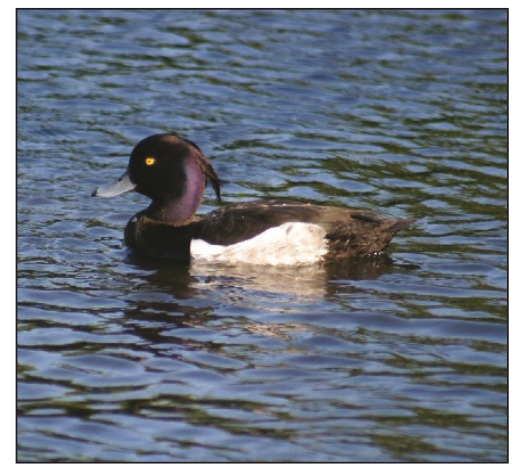

Figure 12: Tufted Duck (Aythya fuligula). Photo: Ronnie Martin.

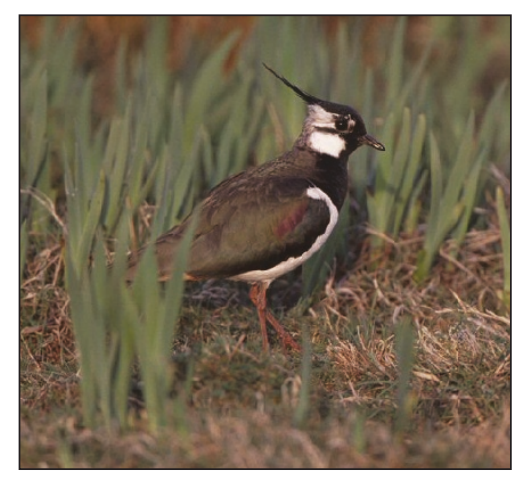

Figure 13: (Northern) Lapwing (Vanellus vanellus). Photo: Billy Clarke.

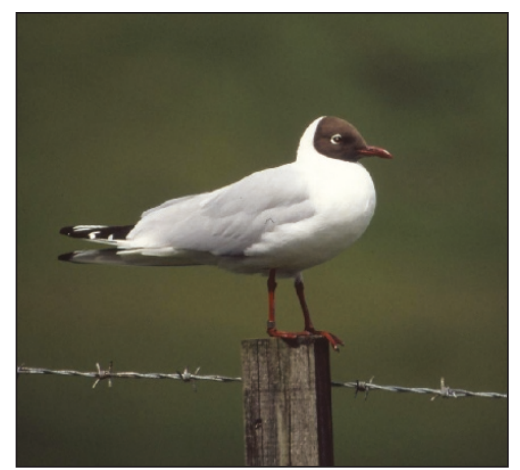

Figure 14: Black-headed Gull (Larus ridibundus). Photo:John Carey.

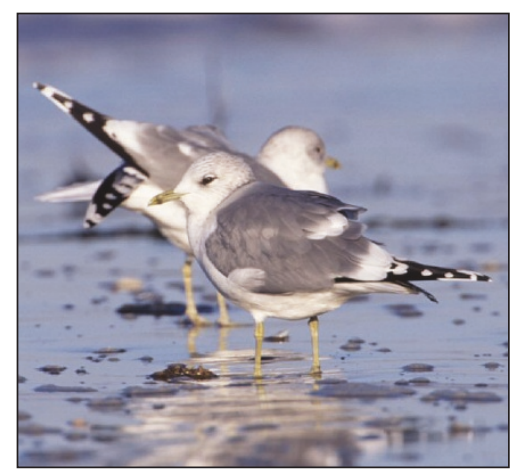

FFigure 15: Common Gull (Larus canus). Photo: Billy Clarke. inland and coastal wetlands, while Pochard, Tufted Duck and Coot are mostly distributed on inland waterbodies (Figure $\mathbf{1 1}$ and Figure 12).

\section{Social interactions}

The marine species listed above are usually found in discrete groups, and seldom interact with other species present inshore, or on inland wetlands. Inland, Little Grebe, Pochard, Tufted Duck and/or Coot are regularly seen feeding together, despite their different feeding habits. Pochard and Coot are primarily vegetarian, while Little Grebes and Tufted Ducks prey on animal material. Tufted Ducks, in particular, also occasionally feed in shallow waters, often alongside dabbling ducks, particularly on spilt grain.

\section{d. Waders}

Distribution and feeding habits

The majority of wader species wintering in Ireland are exclusively coastal throughout the winter period. Here, they prey largely on marine invertebrates present in sandy and muddy substrates of estuaries, open coast and along rocky shoreline.

A number of wader species, namely Oystercatcher, Golden Plover, Lapwing, Jack Snipe, Snipe, Woodcock, Blacktailed Godwit and Curlew, also forage on a variety of soil and surface-feeding invertebrates present in farmland. Oystercatchers and Black-tailed Godwits use mostly coastal grasslands, while Golden Plover, Lapwing, Jack Snipe, Snipe, Woodcock and Curlew are much more widely distributed on a variety of both coastal and inland sites. Both Golden Plover and Lapwing (Figure 13) are also known to forage on grassland sites at night, possibly to avoid Black-headed and Common Gulls (see below).

\section{Social interactions}

Waders are highly gregarious, and large numbers occur on coastal sites in Ireland. Inland, Lapwing and Golden Plover flocks often mix, and occasionally include other species, such as Black-headed Gull. Curlew are often also present, but in general tend to form more discrete flocks. Jack Snipe, Snipe and Woodcock are skulking species, are highly elusive, and are less likely to interact with the above species.

\section{e. Gulls}

Distribution and feeding habits

Gull species occurring in Ireland are predominantly coastal. Most tend to feed at sea, on fish and on offal discarded from fishing trawlers. Some, such as Herring Gull, scavenge close to human habitation, particularly on rubbish tips. Black-headed and Common Gulls (Figure $\mathbf{1 4}$ and $\mathbf{1 5}$ ) also occur on a variety of coastal and inland farmland sites throughout the country, where they forage for earthworms and other soil invertebrates.

Social interactions

The feeding and roosting habits of most gull species wintering in Ireland are broadly similar, and large numbers regularly assemble, particularly on coastal sites throughout the Irish coastline. Additionally, Black-headed Gull and Common Gull 
occur, often together, on a variety of inland sites. Here, they are associated with wetlands, but also regularly occur on pasture. They are often recorded feeding alongside Golden Plover and Lapwing. Both gull species are known to parasitise Golden Plover and Lapwing.

\section{CONCLUSION}

Ireland is attractive to a wide variety of waterbirds, due to the variety and abundance of wetlands. During the winter, over $1 \mathrm{~m}$ waterbirds, comprising mostly migrants from arctic and boreal breeding areas, spend the winter in Ireland, congregating predominantly on wetland sites, and occurring alongside resident waterbirds, often in large mixed-species flocks. There is very substantial mixing of waterbird populations in Ireland, throughout Europe and internationally. Throughout Ireland, there is interaction between different waterbird populations (breeding migrants, the wintering migrants and resident waterbird populations) and species. There is also a regular and complex pattern of movement between feeding and roosting areas, and between wetlands and farmland, which will each also increase the mixing of waterbird species and populations. These interactions are likely to facilitate the rapid transmission and spread of the H5N1 avian influenza virus, if it were present in Ireland.

\section{ACKNOWLEDGEMENTS}

I-WeBS is a joint project of BirdWatch Ireland and NPWS, and relies on hundreds of dedicated volunteers and staff of partner organisations.

\section{REFERENCES}

Boere GC, Stroud DA (2006) The flyway concept: what it is and what it isn't. Waterbirds around the world. Eds G.C. Boere, C.A. Galbraith, D.A. Stroud. The Stationery Office, Edinburgh, UK. pp. 40-49.

Crowe 0 (2005) Ireland's Wetlands and their Waterbirds: Status and Distribution. BirdWatch Ireland, Wicklow.

Crowe O, Austin GE, Colhoun K et al. (2008) Estimates and trends of waterbird numbers wintering in Ireland 1994/95-2003/04. Bird Study 55, 66-77.

Davidson NC, Pienkowski MW (eds). (1987) The conservation of international flyway populations of waders. Wader Study Group Bulletin 49 (Supplement), $1-151$.

DAFF (2009) Avian influenza information, Department of Agriculture and Food. Available from: http://www.agriculture.gov.ie/avian_influenza/ [Accessed 14 September 2009].

EFSA (2006) Opinion on migratory birds and their possible role in the spread of highly pathogenic avian influenza. The European Food Safety Authority Journal 357, 1-46.

EFSA (2008) Scientific Opinion of the Panel on Animal Health and Welfare on a request from The European Commission on Animal health and welfare aspects of avian influenza and the risk of its introduction into the EU poultry holdings. The European Food Safety Authority Journal 715, 1-161.
European Commission (2006) Council Directive 79/409/ EEC of 2 April 1979 on the conservation of wild birds, and its amending acts. Availabe from:

http://europa.eu/legislation_summaries/environment/ nature_and_biodiversity/I28046_en.htm [Accessed 14 September 2009].

European Commission (2007) Avian influenza, DG Health and Consumer Protection. Available from:

http://ec.europa.eu/food/animal/diseases/ controlmeasures/avian/index_en.htm\#ai_response> [Accessed 14 September 2009].

Gibbons DW, Reid JB and Chapman RA (1993) The New Atlas of Breeding Birds in Britain and Ireland: 19881991. T. \& A. D. Poyser, London.

Hutchinson CD (1979) Ireland's Wetlands and Their Birds. Irish Wildbird Conservancy, Dublin.

Kilpatrick AM, Chmura AA, Gibbons DW, Fleischer RC, Marra PP, Daszak P (2006) Predicting the global spread of H5N1 avian influenza. Proc Natl Acad Sci USA 103, 19368-19373

Ramsar Convention Secretariat (2007) Designating Ramsar sites: The Strategic Framework and guidelines for the future development of the List of Wetlands of International Importance. Ramsar handbooks for the wise use of wetlands, 3rd edition, vol. 14. Ramsar Convention Secretariat, Gland, Switzerland. Available from: http://www.ramsar.org/pdf/lib/lib_ handbooks2006_e14.pdf>. [Accessed 14 September 2009].

Ridgill SC, Fox AD (1990) Cold weather movements of waterfowl in Western Europe. International Waterfowl Research Bureau Special Publication No. 13. IWRB, Slimbridge.

Sheppard R (1993) Ireland's Wetland Wealth. Irish Wildbird Conservancy, Dublin.

Stroud DA, Davidson NC, West R et al. (compilers) on behalf of The International Wader Study Group (2004). Status of migratory wader populations in Africa and Western Eurasia in the 1990s. International Wader Studies 15, 1-259.

Webster RG, Bean WJ, Gorman OT et al. (1992) Evolution and ecology of influenza A viruses. Microbiol Rev 56, 152-79.

Webster RG, Hulse-Post DJ, Sturm-Ramirez KM et al. (2007a) Changing epidemiology and ecology of highly pathogenic avian H5N1 influenza viruses. Avian Dis 51, 269-272.

Webster RG, Krauss S, Hulse-Post D et al. (2007b) Evolution of influenza A viruses in wild birds. J Wildl Dis 43, S1-S6

Wernham CV, Toms MP, Marchant JH et al. (2002) The Migration Atlas: movements of the birds of Britain and Ireland. T. \& A. D. Poyser, London.

Wetlands International (2002) Waterfowl population estimates, 3rd Edition. Wetlands International Global Series No. 12, Wageningen, The Netherlands. 